\title{
Cytotaxonomy of Meliaceae
}

\author{
P. C. Datta and P. Samanta \\ Botanical Laboratory of Pharmaco-anatomy, University of Calcutta, \\ Calcutta 700019 , India
}

Received September 9, 1975

Interrelations within the family differ according to authors. Sequences that have been suggested are:

1) Bentham and Hooker (1862) - Melieae - Trichilieae - Swietenieae - Cedreleae.

2) Kribs (1930) - Swietenioideae - Melioideae - Lovoinoideae.

3) Scholz (1964) - Cedreloideae (Cedeleae - Ptaeroxylae) - Swietenioideae - Melioideae (Carapeae - Turraeae - Vavaceae - Melieae - Trichilieae).

4) Hutchinson (1969) - Cedreleae - Swietenieae - Trichilieae - Melieae.

So the attempt was to collect as much informations as possible, of the chromosome number and morphology and to try those informations in solving some controversies.

\section{Materials and methods}

Root tips from cuttings were squashed by usual aceto-orcein technique after pretreatment with saturated solution of aesculine. Figures were drawn with cameralucida at a projected magnification of 2200 , which were drawn by enlarging thrice by projecting.

The species are: Melia azedarach L. (Indian Botanic Garden, Calcutta, P. Samanta, 34); Azadirachta indica A. Juss. (Indian Botanic Garden, Calcutta, P. Samanta, 35); Walsura piscida Roxb. (Indian Botanic Garden, Calcutta, P. Samanta, 38); Aglaia odorata Lour. (Indian Botanic Garden, Calcutta, P. Samanta, 37); Swientenia macrophylla King ;Indian Botanic Garden, Calcutta, P. Samanta, 32); S. mahagoni Jacq. (Indian Botanic Garden, Calcutta, P. Samanta, 33); Toona ciliata Roem. (Indian Botanic Garden, Calcutta, P. Samanta, 34).

\section{Results and conclusion}

Karyotype and chromosome number

Chromosome study of this woody family is very difficult, particularly for troubles in staining. The seven species examined here show the following chromosome types (Fig. 1):

A: Of the three segments formed by two constrictions, the middle longest, two terminals shorter and unequal.

B: Of the three segments formed by two constrictions, the middle longest, two terminals shorter and equal. 
C: Of the three segments formed by two constrictions, the shortest and the longest at two ends.

D: Of the three segments formed by two constrictions, the shortest at one end, the other two longer and equal.
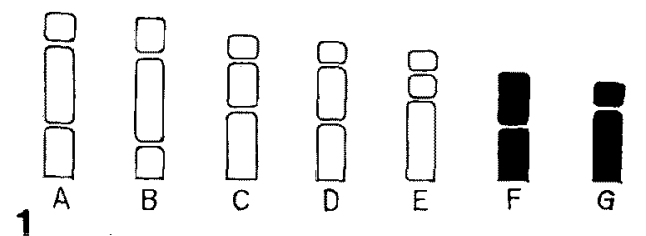

2
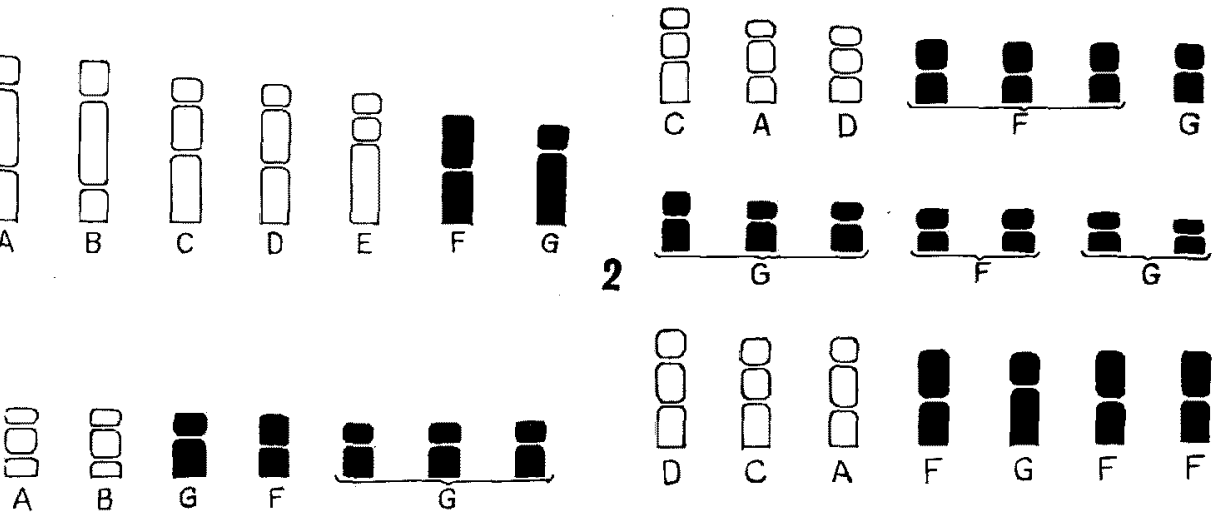

A
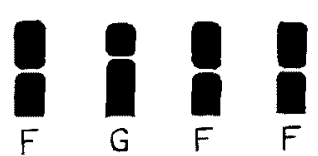

3
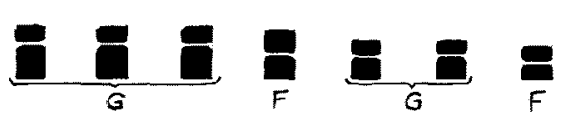

4

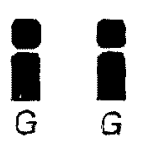

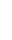

Figs. 1-4. 1, chromosome types observed in the study. 2, idiogram for Melia azedarach. 3, idiogram for Azadirachta indica. 4, idiogram of Walsura piscida.

E: Of the three segments formed by two constrictions, the longest at one end, the other two shorter and equal.

$\mathrm{F}$ : One median constriction forming equal arms.

$\mathrm{G}$ : One submedian constriction forming unequal arms.

On this basis, the karyotype of the seven species can be represented in Table 1 (Figs. 2-8). Meiosis was studied in Azadirachta indica, which revealed clear 14 bivalents in metaphase I and 14 chromosomes in metaphase II. Division was normal.

Table 2 represents the reports of chromosome numbers of Meliaceae.

Basic numbers for the family

Although the family has been variously related to other taxa by different taxonomists, recent anatomical (Heimsch 1942, Metcalfe and Chalk 1950) and chemotaxonomical (Charkavorty and Datta 1969) studies showed that Rutaceae, Simaroubaceae, Sapindaceae, Burseraceae, Anacardiaceae and Meliaceae form a more or less natural group. The basic numbers of chromosome are: 9 and 10 for Rutaceae, 9 for Simaroubaceae; $10-11$ for Sapindaceae, 13 for Burseraceaev 10-14 for Anacardiaceae (vide Darlington and Wylie 1955).

In Meliaceae, the reported numbers are mostly multiples of $9,10,11,12,13$ and 14.

In tribe I Melieae, $\mathrm{x}=14$ (in Melia, Azadirachta and Pterorhachis), or 12 (if $2 n=50$ is derived as $12 \times 4+2$, that is two chromosomes are added to a tetraploid as in 
Turraea and Cipadessa. Similarly $2 \mathrm{n}=58$ in Calodecaryia, Naregamia, Nymania, Munronia may be derived as $14 \times 4+2$, that is two chromosomes were added to a tetraploid with basic 14 .

In tribe II Trichilieae of B. and H., Dysoxylum, Amoora, Aglaia, Turracanthus have $(9-10) \times 4,8$ or 10 , Sandoricum $\mathrm{x}=11$; Chisocheton $(11 \times 4+2)$, Lansium, Guarea,

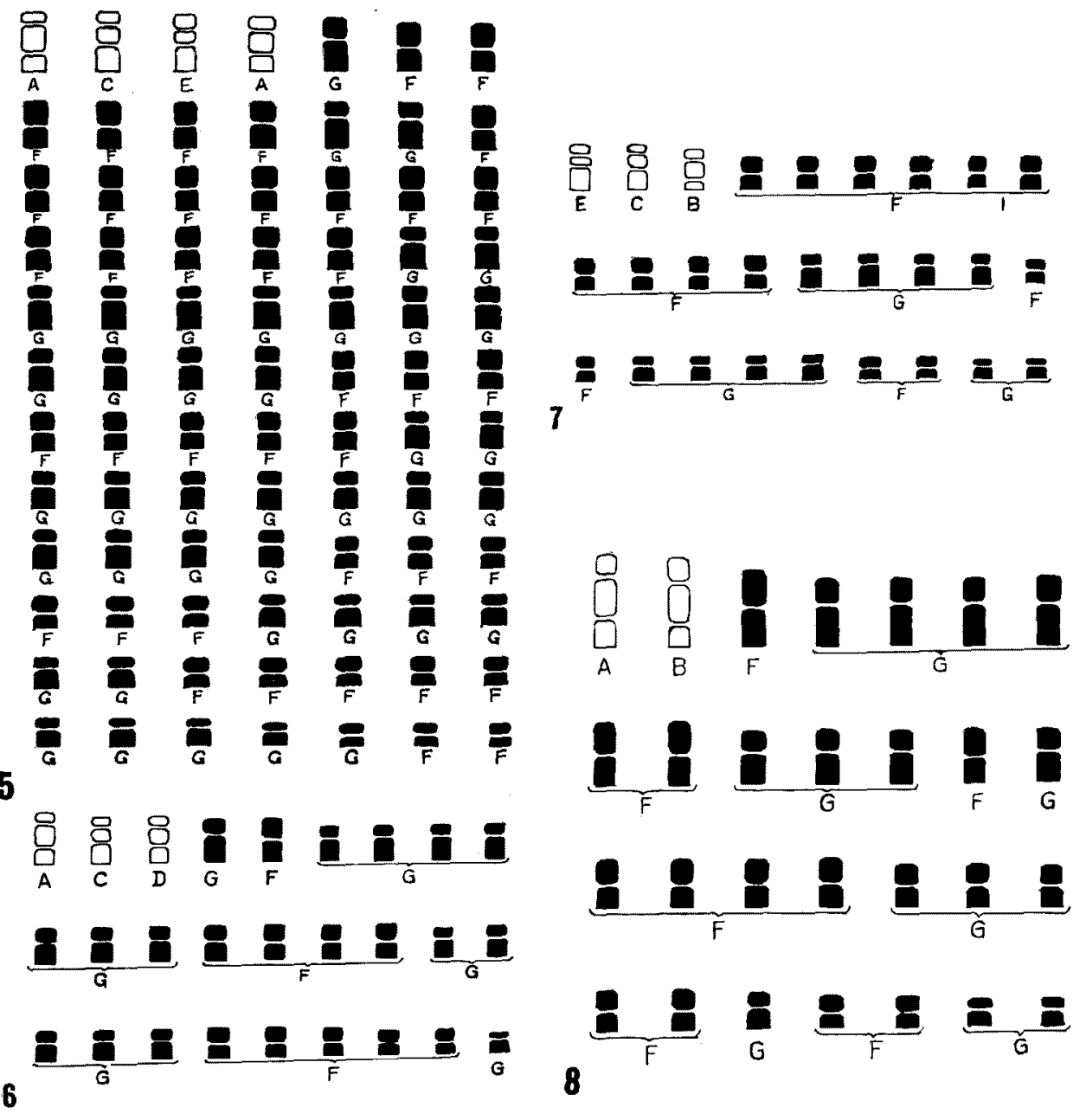

Figs. 5-8. 5, idiogram of Aglaia odorata. 6, idiogram of Swietenia macrophylla. 7, idiogram of S. mahagoni. 8, idiogram of Toona ciliata.

etc. $\mathrm{x}=12(12 \times 6)$; Heynea, Trichilia, Walsura, $\mathrm{x}=14(14 \times 2)$; Pseudobersama, Trichilia, Ekebergia, Lepidotrichilia $\mathrm{x}=12(12 \times 4+2$ or $-2=50$ or 46$)$; Carapa and Xylocarpus $\mathrm{x}=14(14 \times 4$ or $14 \times 4+2)$; Aphanamixis has probably $9 \times 4$.

In tribe III Swietenieae, Swietenia, Soymida and Pseudocedrela have $\mathrm{x}=13(13 \times 4$, or $13 \times 4+2$ ), Khaya, Neobeguea, Lovoa have probably $12 \times 4$ or $12 \times 4+2$, Chukrasia $13 \times 2$, Entrandrophragma $12 \times 3$ or $12 \times 6$ (secondarily balanced).

In tribe IV Cedreleae, Cedrela and Toona have $\mathrm{x}=12,13$ or $14(12 \times 2,12 \times 4$, $12 \times 4+2,13 \times 4,13 \times 6,14 \times 4)$. 
It seems that from lower basic numbers like 9 or 10 , the higher basic numbers like $11,12,13$ or 14 have evolved in the interlinked plexus of Rutaceae, Meliaceae, Simaroubaceae, Burseraceae, Anacardiaceae and Sapindaceae. But the links are almost impossible to trace. Since all the basic lines are represented by the family Meliaceae, a polyphyletic origin of the genera of the family seems to be the most

Table 1. Chromosome characters of a few species examined here

\begin{tabular}{|c|c|c|c|c|c|c|}
\hline Species & $2 n$ & Size range & $\begin{array}{l}\text { Comple } \\
\text { some } \\
\text { withou }\end{array}$ & $\begin{array}{l}\text { ts; chr } \\
\text { es with } \\
\text { onstrict }\end{array}$ & $\begin{array}{l}\text { mo- } \\
\text { or } \\
\text { ons }\end{array}$ & $\begin{array}{l}\text { Position of } \\
\text { primary } \\
\text { constric- } \\
\text { tions* }\end{array}$ \\
\hline \multirow[t]{5}{*}{ Melia azedarach } & 28 & $0.7-1.3-2.2$ & with & $2 \mathrm{~A}$ & 6 & $\mathrm{sm}$ \\
\hline & & & & $2 \mathrm{C}$ & & $\mathrm{m}$ \\
\hline & & & & $2 \mathrm{D}$ & & $\operatorname{sm}$ \\
\hline & & & without & $10 \mathrm{~F}$ & 22 & $\mathrm{~m}$ \\
\hline & & & & $12 \mathrm{G}$ & & sm \\
\hline \multirow[t]{4}{*}{ Azadirachta indica } & 28 & $0.7-1.2-1.6$ & with & $2 \mathrm{~A}$ & 4 & $\mathrm{sm}$ \\
\hline & & & & $2 B$ & & $\mathrm{sm}$ \\
\hline & & & without & $6 \mathrm{~F}$ & 24 & $\mathrm{~m}$ \\
\hline & & & & $18 \mathrm{G}$ & & $\mathrm{sm}$ \\
\hline \multirow[t]{5}{*}{ Walsura piscida } & 28 & $1.18-1.88-2.65$ & with & $2 \mathrm{~A}$ & & $\mathrm{sm}$ \\
\hline & & & & $2 \mathrm{C}$ & 6 & $\mathrm{~m}$ \\
\hline & & & & $2 \mathrm{D}$ & & $\mathrm{sm}$ \\
\hline & & & without & $10 \mathrm{~F}$ & 22 & $\mathrm{~m}$ \\
\hline & & & & $12 \mathrm{G}$ & & $\mathrm{sm}$ \\
\hline \multirow[t]{5}{*}{ Aglaia odorata } & 168 & $0.6-1.0-1.5$ & with & $4 \mathrm{~A}$ & & $\mathrm{sm}$ \\
\hline & & & & $2 \mathrm{C}$ & 8 & $\mathrm{~m}$ \\
\hline & & & & $2 \mathrm{E}$ & & $\mathrm{m}$ \\
\hline & & & without & $80 \mathrm{~F}$ & & $\mathrm{~m}$ \\
\hline & & & & $80 \mathrm{G}$ & 160 & $\mathrm{sm}$ \\
\hline \multirow[t]{5}{*}{ Swietenia macrohylla } & 54 & $0.6-1.0-1.6$ & with & $2 \mathrm{~A}$ & & sm \\
\hline & & & & $2 \mathrm{C}$ & 6 & $\mathrm{~m}$ \\
\hline & & & & $2 \mathrm{D}$ & & $\mathrm{sm}$ \\
\hline & & & without & $20 \mathrm{~F}$ & 48 & $\mathrm{~m}$ \\
\hline & & & & $28 \mathrm{G}$ & & sm \\
\hline \multirow[t]{5}{*}{ S. mahagoni } & 54 & $0.51-0.9-1.5$ & with & $2 \mathrm{~B}$ & & $\mathrm{sm}$ \\
\hline & & & & $2 \mathrm{C}$ & 6 & $\mathrm{~m}$ \\
\hline & & & & $2 \mathrm{E}$ & & $\mathrm{m}$ \\
\hline & & & without & $28 \mathrm{~F}$ & 48 & $\mathrm{~m}$ \\
\hline & & & & $20 \mathrm{G}$ & & sm \\
\hline \multirow[t]{4}{*}{ Toona ciliata } & 56 & $0.7-1.4-2.6$ & with & $2 \mathrm{~A}$ & 4 & $\mathrm{sm}$ \\
\hline & & & & $2 B$ & & $\mathrm{sm}$ \\
\hline & & & without & $24 \mathrm{~F}$ & 52 & $\mathrm{~m}$ \\
\hline & & & & $28 \mathrm{G}$ & & sm \\
\hline
\end{tabular}

* $\mathrm{m}=$ median; $\mathrm{sm}=$ submedian. 
Table 2. Reports on chromosome number (arrangement mainly based on Bentham and Hooker 1862)

\begin{tabular}{|c|c|c|c|}
\hline \multirow[t]{2}{*}{ Species } & \multicolumn{2}{|c|}{$\begin{array}{l}\text { Chromosome } \\
\text { number }\end{array}$} & \multirow[t]{2}{*}{ Authors } \\
\hline & $\bar{n}$ & $2 n$ & \\
\hline \multicolumn{4}{|l|}{ Tribe I. MeLIEAE } \\
\hline Turraea floribunda Hochst. & - & 58 & Minfray $1963 b$ \\
\hline T. heterophylla Sm. & - & 50 & $\begin{array}{c}\text { Mangenot and Mangenot } \\
1957\end{array}$ \\
\hline T. nilotica Kot. and Peyr. & - & 50 & - do- \\
\hline T. obtusifolia Hochst. & - & 50 & - do- \\
\hline T. robusta Grüke & - & 50 & $-\mathrm{do}-$ \\
\hline T. sp. Nov. & - & 50 & - do- \\
\hline T. yogelioides Bagsh & - & 50 & - do- \\
\hline \multicolumn{4}{|l|}{ * Calodecaryia crassifolia } \\
\hline \multirow[t]{2}{*}{ J. F. Leroy } & - & 58 & Minfray $1963 b$ \\
\hline & - & 36 & Styles and Vosa 1971 \\
\hline \multirow[t]{2}{*}{ Naregamia allata Wight and Arn. } & - & 58 & Minfray $1963 b$ \\
\hline & - & 46 & Styles and Vosa 1971 \\
\hline \multirow[t]{2}{*}{ * Nymania capensis (Thunb.) Lindo } & - & 58 & Minfray $1963 b$ \\
\hline & - & 40 & Styles and Vosa 1971 \\
\hline \multirow[t]{2}{*}{ Munronia pinnata (Wall.) Harms } & - & 58 & Minfray $1963 b$ \\
\hline & - & 50 & Styles and Vosa 1971 \\
\hline \multirow[t]{6}{*}{ Melia azedarach $\mathrm{L}$. } & - & 28 & Minfray 1963 \\
\hline & - & 28 & Pathak et al. 1949 \\
\hline & - & 28 & Bowden 1945 \\
\hline & - & 28 & Gadella et al. 1966 \\
\hline & - & 28 & Present report \\
\hline & 14 & - & Zerpa 1953 \\
\hline M. azedarach var. "gigante" & 14 & - & Mehra and Khosla 1969 \\
\hline$M$. composita Willd. & 14 & - & - do- \\
\hline Melia floribunda Curr. & - & 28 & Minfray $1963 b$ \\
\hline M. toosandan Sieb. and Zucc. & - & 28 & Minfray $1963 b$ \\
\hline \multirow[t]{5}{*}{ Azadirachta indica A. Juss. } & - & 30 & Mangenot and Mangenot 1958 \\
\hline & - & 28 & Bowden 1945 \\
\hline & - & 28 & Pathak et al. 1949 \\
\hline & 14 & - & Mukherjee 1952 \\
\hline & 14 & 28 & Present report \\
\hline Cipadessa baccifera (Roth.) Miq. & - & 50 & Mangenot and Mangenot 1957 \\
\hline $\begin{array}{l}\text { C. cinerascens (Pell.) Hand.- } \\
\text { Zazz. }\end{array}$ & - & 50 & - do- \\
\hline \multicolumn{4}{|l|}{ Tribe II. TRICHILIEAE } \\
\hline Dysoxylum binectariferum $\mathrm{Hk} . \mathrm{f}$. & 40 & - & Mehra and Khosla 1969 \\
\hline D. hamiltonii Hiern & 40 & - & - do- \\
\hline D. pachyphyllum Hems. & 40 & - & - do- \\
\hline D. pallens Hiern & 10 & - & - do- \\
\hline D. procerum Hiern & 40 & - & - do- \\
\hline D. ramiflorum Miq. & 36,38 & - & Paetow 1931 \\
\hline D. spectabile (Frost. f.) Hk. f. & 42 & - & Beuzenberg and Hair 1963 \\
\hline \multirow[t]{2}{*}{ *Turraeanthus africana (W.) Pell. } & - & 150 & Mangenot et al. 1957 \\
\hline & - & 100 & $\begin{array}{c}\text { Mangenot and Mangenot } \\
1962\end{array}$ \\
\hline
\end{tabular}


Table 2 (Contd.)

\begin{tabular}{|c|c|c|c|}
\hline \multirow[t]{2}{*}{ Species } & \multicolumn{2}{|c|}{$\begin{array}{l}\text { Chromosome } \\
\text { number }\end{array}$} & \multirow[t]{2}{*}{ Authors } \\
\hline & $\mathrm{n}$ & $2 n$ & \\
\hline Chisocheton paniculatus Hiern & 23 & - & Mehra and Khosla 1969 \\
\hline Sandoricum indicum Cav. & - & 16,32 & Tixier 1958 \\
\hline S. koetjape (Burm. f.) Merr. & 11,22 & - & Ramirez 1961 \\
\hline Aglaia edulis A. Gray & 40 & - & Mehra and Khosla 1969 \\
\hline Ag. odorata Lour. & - & 168 & Present report \\
\hline Ag. perviridis Hiern & 20 & - & Mehra and Khosla 1969 \\
\hline Lansium domesticum Corr. & 72 & - & Bernardo and Ramirez 1959 \\
\hline Aphanamixis polystachaya Park. & 18 & - & Mehra and Khosla 1969 \\
\hline A. rohituka (Roxb.) Pierre & - & 76 & Minfray $1963 b$ \\
\hline Amoora spectabilis Miq. & 20 & - & Mehra and Khosla 1969 \\
\hline Guarea cedrata (A. Chev.) Pell. & - & 150 & Mangenot et al. 1957 \\
\hline \multirow[t]{2}{*}{ G. thompsonii sp. and Hut. } & - & c. 72 & $\begin{array}{l}\text { Mangenot and Mangenot } \\
\qquad 1962\end{array}$ \\
\hline & - & 72 & $\begin{array}{c}\text { Mangenot and Mangenot } \\
1957\end{array}$ \\
\hline \multicolumn{4}{|l|}{ Ekebergia benguelensis } \\
\hline (Well) C. DC. & - & 50 & $\begin{array}{c}\text { Mangenot and Mangenot } \\
1957\end{array}$ \\
\hline E. capensis Sparrm & - & 50 & Mangenot and Mangenot 1957 \\
\hline \multicolumn{4}{|l|}{${ }^{*}$ Capuronianthus mahafalensis } \\
\hline Leroy & - & 58 & Minfray $1963 a, b$ \\
\hline Carapa grandiflora Spr. & - & 56 & Minfray $1963 a$ \\
\hline C. guianensis Aubl. & - & 58 & Minfray $1963 \mathrm{a}$ \\
\hline Carapa procera $\mathrm{DC}$. & - & 58 & Minfray $1963 a$ \\
\hline \multicolumn{4}{|l|}{$X$. moluccensis (Lam.) M. J. } \\
\hline Roem. & - & 58 & $-\mathrm{do}-$ \\
\hline \multirow{2}{*}{ Walsura piscida Roxb. } & 14 & 28 & Ghosh 1961,1968 \\
\hline & - & 28 & Present report \\
\hline \multirow[t]{2}{*}{ Heynea trijuga Roxb. } & - & 24 & Nanda 1962 \\
\hline & 14 & - & Mehra and Sareen 1969 \\
\hline \multirow[t]{2}{*}{ Lepidotrichilia volkensee Leroy } & - & 50 & $\begin{array}{c}\text { Mangenot and Mangenot } \\
1957\end{array}$ \\
\hline & - & 38 & Styles and Vosa 1971 \\
\hline \multicolumn{4}{|l|}{ Pseudobersama mosambicensis } \\
\hline \multirow[t]{2}{*}{ (Sim) Verdc. } & - & 50 & $\begin{array}{c}\text { Mangenot and Mangenot } \\
1957\end{array}$ \\
\hline & - & 46 & Styles and Vosa 1971 \\
\hline \multirow{2}{*}{ *Pterorachis zenkeri Harms } & 14 & 28 & Nanda 1962 \\
\hline & & & $\begin{array}{l}\text { Mehra and Sareen } 1969 \\
\text { Styles and Vosa } 1971\end{array}$ \\
\hline Trichilia amentica & - & 50 & Mangenot and Mangenot 1957 \\
\hline \multirow[t]{2}{*}{ Tr. cannaroides (W. and A.) } & 14 & - & Rao 1967 \\
\hline & 14 & - & Mehra and Sareen 1969 \\
\hline Tr. dregeana Sond & 14 & - & -do- \\
\hline Tr. emetica Vahl & - & 50 & Mangenot and Mangenot 1957 \\
\hline Tr. hendelottii Plan. & - & 50 & - do \\
\hline
\end{tabular}


Table 2 (Contd.)

\begin{tabular}{|c|c|c|c|}
\hline \multirow{2}{*}{ Species } & \multicolumn{2}{|c|}{$\begin{array}{l}\text { Chromosome } \\
\text { number }\end{array}$} & \multirow{2}{*}{ Authors } \\
\hline & $\mathrm{n}$ & $2 n$ & \\
\hline Tr. lanata A. Chev. & - & 50 & - do- \\
\hline Tr. odorata Andr. & - & 92 & Minfray $1963 b$ \\
\hline Tr. prieuriana A. Juss. & - & 50 & Mangenot and Mangenot 1957 \\
\hline Tr. rubescens Oliv. & - & 50 & Mangenot and Mangenot 1957 \\
\hline \multicolumn{4}{|l|}{ Tribe III. SWIETENIEAE } \\
\hline Swietenia humilis Zucc. & - & 50,52 & Minfray $1963 a$ \\
\hline \multirow[t]{2}{*}{ Sw. macrophylla King } & - & 54 & - do- \\
\hline & - & 54 & Present report \\
\hline \multirow[t]{2}{*}{ Sw. mahagoni (L.) Jacq. } & - & $46-48$ & $\begin{array}{l}\text { Krishnaswamy and Raman } \\
1949\end{array}$ \\
\hline & - & 54 & Present report \\
\hline Khaya anthotheca (Welw.) C. DC. & - & 50 & Mangenot and Mangenot 1957 \\
\hline K. grandifoliola C. DC. & - & 50 & - do- \\
\hline \multirow[t]{2}{*}{$K$. ivorensis A. Chev. } & - & 50 & - do- \\
\hline & - & $46-48$ & Miege 1954 \\
\hline \multicolumn{4}{|l|}{ K. madagascariensis Jumel. } \\
\hline and Perr. & - & 50 & Mangenot and Mangenot 1957 \\
\hline \multirow[t]{3}{*}{ K. nyasica (Des.) Juss. } & - & 50 & Miege 1960 \\
\hline & - & 46 & Minfray $1963 a, b$ \\
\hline & - & 50 & Mangenot and Mangenot 1958 \\
\hline K. senegalensis (Desv.) Juss. & - & 50 & $\begin{array}{l}\text { Miege } 1960 \text {; } \\
\text { Mangenot and Mangenot } 1958\end{array}$ \\
\hline$K$. senegalensis & - & 46 & Minfray $1963 b$ \\
\hline Soymida febrifuga Juss. & - & 52 & Minfray $1963 a$ \\
\hline Soymida febrifuga & - & 56 & Styles and Vosa 1971 \\
\hline Chukrasia tabularis Juss. & 13 & - & Rao 1967 \\
\hline \multicolumn{4}{|l|}{ *Entandrophragma angolense } \\
\hline \multirow[t]{2}{*}{ (Welw.) C. DC. } & - & 36,72 & $\begin{array}{l}\text { Nanda 1962; } \\
\text { Mangenot and Mangenot } 1957\end{array}$ \\
\hline & - & 66 & Miege 1954 \\
\hline E. cordatum (Spr.) Spr. & - & 36 & Mangenot and Mangenot 1957 \\
\hline E. cylindricum $\mathrm{Sp}$. & - & 36,72 & - do- \\
\hline E. delevoyi DC. Wild. & - & 36 & - do- \\
\hline E. exelsum (Dawe) Spr. & - & 36 & Mangenot and Mangenot 1957 \\
\hline E. utile (Dawe and Spr.) Spr. & - & 72 & - do- \\
\hline Lovoa swynnertonii Bak. f. & - & 52 & Styles and Vosa 1971 \\
\hline L. trichilioides Harms & - & 50 & Mangenot and Mangenot 1957 \\
\hline \multirow[t]{2}{*}{ Neobeguea mahafalensis Leroy } & - & $50-52$ & Minfray $1963 b$ \\
\hline & - & 50 & Styles and Vosa 1971 \\
\hline \multicolumn{4}{|l|}{ Pseudocedrela kothchoyi } \\
\hline (Schweinf.) Harms & - & 50,52 & Minfray 1963 \\
\hline \multicolumn{4}{|l|}{ Tribe IV. CEDRELEAE } \\
\hline \multicolumn{4}{|l|}{ Cedrela angustifolia Sesse } \\
\hline and Moc. ex C. DC. & - & 46,48 & $\begin{array}{c}\text { Krishnaswamy and Raman } \\
1949\end{array}$ \\
\hline C. fissilis Vell. & - & 46,48 & - do- \\
\hline C. mexicana M. Roem. & - & 56 & Minfray $1963 b$ \\
\hline C. microcarpa DC. & 12 & - & Mehra and Khosla 1969 \\
\hline
\end{tabular}


Table 2 (Contd.)

\begin{tabular}{|c|c|c|c|}
\hline \multirow{2}{*}{ Species } & \multicolumn{2}{|c|}{$\begin{array}{c}\text { Chromosome } \\
\text { number }\end{array}$} & \multirow{2}{*}{ Authors } \\
\hline & $\mathrm{n}$ & $2 n$ & \\
\hline C. odorata Linn. & - & $50-52$ & Simmonds 1954 \\
\hline C. sinensis A. Juss. & - & 56 & Minfray $1963 b$ \\
\hline \multirow[t]{4}{*}{ Toona ciliata M. Roem } & 26 & - & Mehra and Sareen 1969 \\
\hline & 28 & - & Mehra and Khosla 1969 \\
\hline & - & 56 & Singh 1951 \\
\hline & - & 56 & Present report \\
\hline T. ciliata var. pillistaminea C. DC. & 39 & - & Mehra and Khosla 1969 \\
\hline T. ciliata var. toona & 28 & - & - do- \\
\hline T. microcarpa (C. DC.) Harms & 12 & - & - do- \\
\hline$T$. serrata (Royle) Roem. & - & 52 & Mehra and Sareen 1969 \\
\hline T. sinensis (A. Juss.) Roem. & 一 & 56 & Minfray $1963 a$ \\
\hline
\end{tabular}

* Not mentioned by Benthan Hooker. This position is based on Harms (1940) modified by Leory (1958) and Styles and Vosa (1971).

reasonable conclusion. The various high chromosome numbers represented by the family can only be explained by assuming their evolution through alloploidy, autoploidy and aneuploidy from the mentioned basic numbers.

Possible trends of evolution of chromosome number in Meliaceae:

It is very difficult to discover a clear principle of evolution of the chromosome numbers of the family, where occurrence of so many secondary basic numbers and high levels of heteroploidy are apparent. Lower basic numbers and diploids should be regarded as lower in gradation. Homoploids $(4 n, 6 n, 8 n)$ should be regarded less advanced than aneuploids $(4 n+2,6 n+2,8 n+2$, etc.). On the basis of this assumption we have made arbitrary divisions or steps of advancement: 1) $(x=9$, $2 \mathrm{n}$; ; $) 9 \times 2+2$ (i. e. $2 \mathrm{n}+2)=10 \times 2(\mathrm{n}=10)$; 3$) 9 \times 4$; or $10 \times 2+2=11 \times 2$; 4) $9 \times 6$ or 8 ; or $9 \times 4+2,11 \times 3-1$; 5) $10 \times 4$; or $11 \times 2+2=12 \times 2$; 6) $10 \times 6$ or 8 ; $10 \times 4+2$; 7) $10 \times 10 ; 11 \times 4$; or $12 \times 2+2=13 \times 2$; 8$) 11 \times 6$ or 8 ; $11 \times 4+2$;9) $12 \times 4$; or $13 \times 2+2=14 \times 2$; 10) $12 \times 6$ or 8 ; or $12 \times 4+2$ or $12 \times 4-2$; 11) $13 \times 4$; or $14 \times 2+2=15 \times 2$; 12) $13 \times 6$ or 8 ; or $13 \times 4+2$; 13) $14 \times 4$; or $(15 \times 2+2=$ $16 \times 2)$; 14) $14 \times 6$ or 8 ; or $14 \times 4+2$. Bracketed conditions are rare in reports.

Thus in Melieae (and Turraeeae), two basic lines of numerical change of chromosomes are noticed (Fig. 9). One from $12 \times 2$ to $12 \times 4$ to $12 \times 4+2$ in Turraea and Cipadessa. The other of $14 \times 2$ in Pterorhachis, Melia and Azadirachta, then to $14 \times 4+2$ in Calodecaryia, Naregamia, Nymania and Munronia. Calodecaryia probably evolved earlier with $9 \times 4$ chromosomes. Cipadessa $(2 \mathrm{n}=50)$ has been placed in Trichilieae by Styles and Vosa (1971). But both chromosome number and external morphology suggest a relation in Turraea.

In Trichileae of older classifications, one line is from $(9 \times 2)$ to $9 \times 4$ in Aphanamixis and Dysoxylum, another is from $10 \times 2$ to $10 \times 4$ (Amoora, Aglaia) to $10 \times 8$ (Aglaia, Dysoxylum), to $10 \times 10$ (Turraeanthus), the third is from $11 \times 2$ to $11 \times 4+2$ (Chisocheton), the fourth is $12 \times 2$ to $12 \times 6$ (Lansium, Guarea and Leplaea). These 


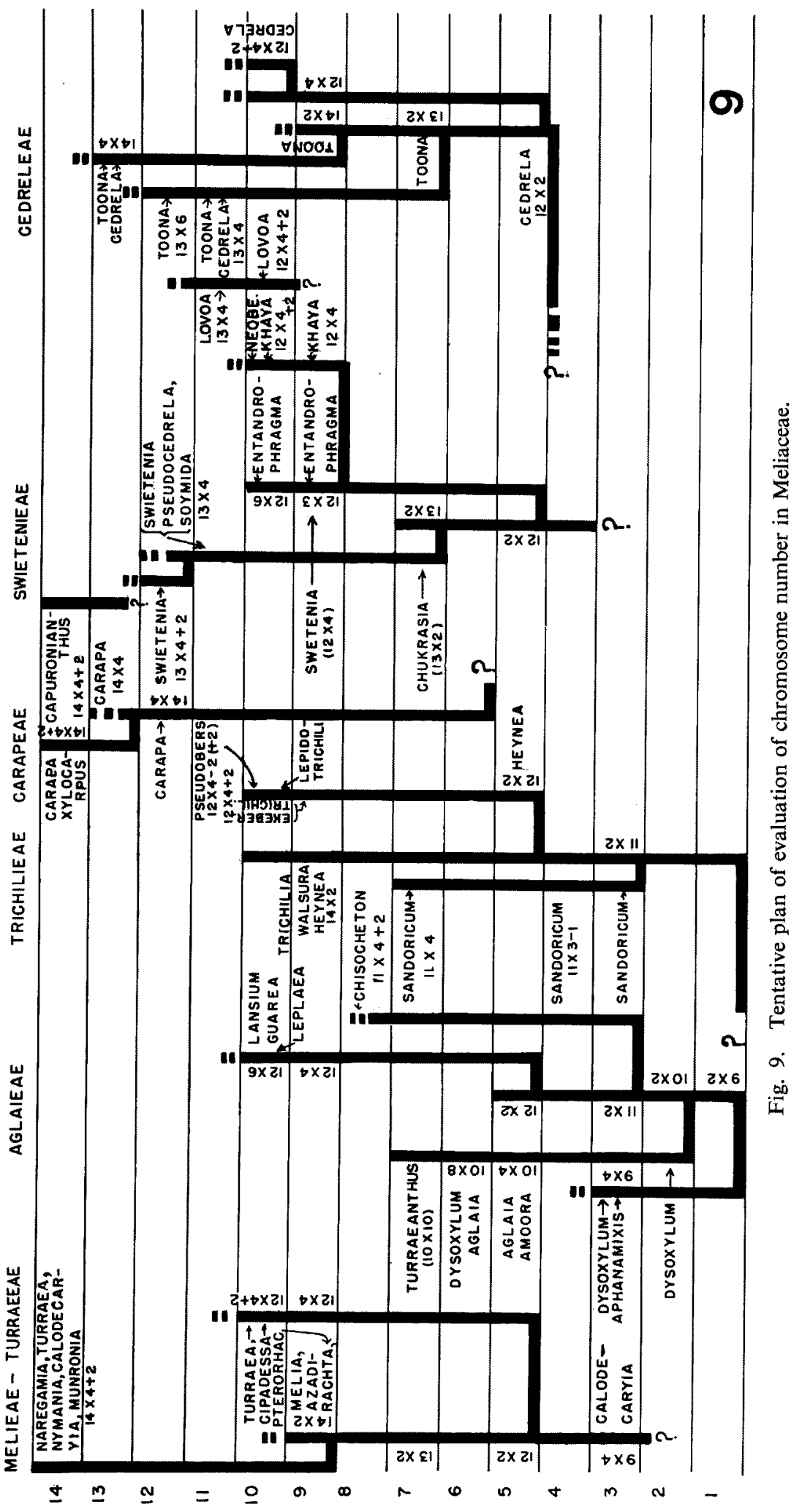


genera form a distinct morphological group (Aglaieae) (Datta and Samanta, In press). The fifth is from $12 \times 2$ to $12 \times 4$ to $12 \times 4+2$ or $12 \times 4-2$ (Heynea, Trichilia, Ekeberaia, Lepidotrichilia, Pseudobersama); which has a side line $14 \times 2$ (Trichilia, Walsura, Heynea); the sixth line is from $11 \times 2$ to $11 \times 3-1$ to $11 \times 4$ (Sandoricum). Trichilia shows very much heterogeneity, $2 \mathrm{n}=50(12 \times 4+2), 92$ $(12 \times 8-4$ ?) and $2 \mathrm{n}=28(14 \times 2)$. In this tribe, the new Trichilieae are anatomically and chemotaxonomically distinct, from genera of Aglaieae (Fig. 9) (Datta and Samanta 1975, Chakraborty and Datta 1969), in which $11 \times 2$ (Sandoricum) and $11 \times 4$ (Sandoricum) form one branch, $11 \times 2$ to $12 \times 2$ to $13 \times 2$ to $14 \times 2$ (Walsura, Heynea etc.) form another branch. Carapa and Xylocarpus $(14 \times 4$ to $14 \times 4+2)$ are cytologically related. Minfray (1963a, b) suggested placing Carapa near Capuronianthus. Styles and Vosa (1971) have, however, suggested conclusively that Carapa and Xylocarpus should be placed in their own tribe under Swietenioideae not under Melioideae (Della De Torre and Harms) nor in the tribe Trichilieae (Bentham and Hooker). Wood anatomy (Datta and Samanta 1975) and chemical informations (Chakraborty and Datta 1969) support this conclusion. Capuronianthus, though has the same number as that of Carapa and Xylocarpus, for morphological difference appears as a distinct line of uncertain origin (Capuronianthoideae).

Swietenieae probably started from $12 \times 2$ (not reported) and evolved in two lines, one of $13 \times 2$ (Chukrasia), $13 \times 4$ (Sovmida, Pseudocedrela and Swietenia) and $13 \times 4+2$ (Swietenia), and the other of $12 \times 3$ and $12 \times 6$ (Entandrophragma) and $12 \times 4$ to $12 \times 4+2$ (Khaya, Neobeguea). Although Lovoa has the chromosome number similar to Khaya, Swietenia, etc. for morphological and anatomical difference (Kribs 1930) should be regarded as a different line (Lovoinoideae).

Tribe Cedreleae needs special mention. Probably 12 was the original basic number (e. g. Cedrela microcarpa with $2 \mathrm{n}=24$ ) from which has evolved the tetraploids $(2 \mathrm{n}=48)$ in $C$. angustifolia, C. fissilis. Probably from that evolved the aneuploid numbers $50(12 \times 4+2)$. Another line from $13 \times 2$ to $42(=13 \times 4)$ has evolved in $C$. odorata. Thus a secondary basic number 13 arrived in $C$. odorata and $T$. T. serrata. Haploid number 39 in Toona ciliata var. pillistaminea is a hexaploid of that number $(13 \times 6)$. Probably by similar progressive aneuploidy a tertiary basic number 14 evolved in $T$. ciliata, $T$. sinensis and $C$. mexicana.

Chromosome morphology appears similar in all the seven species studied here. Length of chromosomes is not different in different species. Number of secondary constriction is proportionately highest in Melia azedarach, lowest in Aglaia odorata. Submedian primary constrictions (i. e. unequal arms) have the highest proportion in Melia and lowest in Aglaia. These facts support a low position of Aglaia, as suggested in the chromosome number chart (Fig. 9). The difference between the chromosome length within a complement is highest in Melia (Melioideae) and Toona (Swietenioideae) and lowest in Walsura. On the whole, the chromosome morphology suggests that Azadirachta, Aglaia and Walsura are comparatively primitive, Melia, Swietenia, Toona and Cedrela comparatively advanced. 


\section{Summary}

Cytological informations of the family Meliaceae suggest $9,10,11,12,13$ and 14 as basic numbers. Numbers have evolved from lower to higher. In Melieae 14 is the basic number. In old Trichilieae the numbers are 9-14, which show different ploidy levels, including aneuploids. Carapa and Xylocarpus are similar in karyology and should be placed as Carapeae near Swietenieae, not with Melieae or Trichilieae. Cedreleae show a wide range of variation $12 \times 2$ to $14 \times 4$ and a highly advanced chromosome morphology. Calodecaryia (some species), Azadirachta, Dysoxylum, Aphanamixis, Aglaia, Amoora, Sandoricum are primitive and Naregamia, Nymania, Calodecaryia (some species), Lansium, Carapa, Xylocarpus, Capuronianthus, Swietenia, Cedrela and Toona are advanced.

\section{References}

Bentham, G. and Hooker, J. D. 1862. Genera Planterum I. Reeve and Co. London 1.

Bernardo, F. A. and Ramirez, D. A. 1959. Cytology of Philippine plants III. Lansium domesticum Corr. Philippine Agriculturist. 43 (5): 375-377.

Beuzenberg, E. T. and Hair, J. B. 1963. Contribution to chromosome atlas of the New Zealand flora. 5. Miscellaneous families. N. Z. Four. Bot. 1: 53-67.

Bowden, W. M. 1945. A list of chromosome numbers in higher plants I. Acanthaceae to Myrtaceae. Amer. Jour. Bot. 32: 81-92.

Chakraborty, T. and Datta, P. C. 1969 . Chemical and botanical characters as aid to the taxonomy of Meliaceae. Bull. Botan. Soc. Bengal (Sen Memo. Vol.): 437-454.

Darlington, C. D. and Wylie, A. P. 1955. Chromosome Atlas of Flowering Plants, London.

Datta, P. C. and Samanta, P. 1975. Wood Anatomy of Indo-Malayan Meliaceae (in press).

Gadella, T. W. J., Kliphuis, E. and Mennega, E. A. 1966 . Chromosome numbers of some flowering plants of Spain and South France. Acta Bot. Neerland. 15: 484-489.

Ghosh, R. B. 1961. Chromosome number of some flowering plants. Curr. Sci. 30: 73.

- 1968. Studies on the morphology of somatic chromosomes in Walsura piscida Roxb. Caryologia $21(2): 111-114$.

Harms, H. 1940. In Engler and Prantl's Die Natürlichen Pflanzenfamilien (2nd Ed.) 19b I.

Heimsch, C. J. 1942. Comparative anatomy of the secondary xylem of the "Gruinales" and "Terebinthales" of Wettstein with reference to taxonomic groupings. Lilloa 8: 154-165.

Hutchinson, J. 1969. Evolution and Phylogeny of Flowering Plants. Academic Press, London \& New York.

Kribs, D. A. 1930. Comparative anatomy of the woods of Meliaceae. Amer. Jour. Bot. 17: 724-738.

Krishnaswamy, N. and Raman, V.S. 1949. A note on the chromosome numbers of some economic plants of India. Curr. Sci. 18: 376-378.

Leroy, J. F. 1958. Un nouveau genre endemique a Madagascar; le Capuronianthus. Jour. Agr. Trop. et Bot. Appl. 5: 762-764.

Mangenot, S. and Mangenot, G. 1957. Nombres chromosomique nouveaux chez. diverse dicotyledones et monocotyledones d'Afrique occidentale. Bull. Fard. Bot. 27: 639-654.

— and - 1958. Deuxieme liste de nombres chromosomiques nouveaux chez. diverses dicotyledones et monocotyledones d'Afrique occidentale. Bull. Fard. Bot. (Bruxelles) 28: 315 329.

Mangenot, S. and Mangenot, G. 1962. Enquete sur les nombres chromosomiques dans une collection, d'especes tropicales. Rev. Cytol. et. Biol. Veget. 25: 412-429.

-, -, Foutrel, G. and Mensbruge, G. 1957. Sur les nombres chromosomiques de 150 escoes d'Angiospermes d'Afrique tropicale. Compte Rend. Acad. Paris. 245: 559-562. 
Mehra, P. N. and Khosla, P. K. 1969. IOPB chromosome number reports (XX). Taxon 18 (2): 216-217.

- and Sareen, T. S. 1969. IOPB Chromosome number reports (XXII). Taxon 18 (4): 404.

Metcalfe, C. L. and Chalk, L. 1950. Anatomy of Dicotyledons. Vol. II. Oxford, at Clarendon Press.

Miege, J. 1954. Nombre chromosomiques et repartition geographique de quelques plantes tropicales et equatororiales. Rev. Cyt. et. Biol. Veg. 15: 312-348.

- 1960. Nombres chromosomiques de plantes d'Afrique occidentales. Rev. Cyt. Biol. Veg. 21 (4): 373-384.

Minfray, E. 1963a. Le noyau et les chromosomes somatique de deux Meliacees. Bull. Mus. Nat. d'Hist. Nat et Ser. 35: 527-531.

- 1963b. Contribution a l'etude caryotaxonomique des Meliacees. Bull. Soc. Bot. France 10: 180-182.

Mukherjee, S. K. 1952. Meiosis in Azadirachta indica A. Juss. Curr. Sci. 21 (10): 287.

Nanda, P. C. 1952. Chromosome numbers of some trees and shrubs. J. Indian Bot. Soc. 41 (2): 271-277.

Paetow, W. 1931. Embryologische Untersuchungen an Taccaceen, Meliaceen und Dilleniaceen. Planta 14: 441-470.

Pathak, G. N., Singh, B., Tiwari, K. M., Srivastava, A. N. and Pande, K. K. 1949. Chromosome numbers in some angiospermous plants. Curr. Sci. 18 (9): 347.

Ramirez, D. A. 1961. Cytology of Philippine plants VI. Sandoricum koetijape (Berin. f.) Merr. Philippine Agriculturist 45: 275-278.

Rao, H. S. 1967. Chromosome counts of new forest plants. Indian For. 93 : 243-254.

Scholz, H. 1964. In A. Angler's Syllabus der Pflanzenfamilien. Band III. Gebrüder Borntraeger, Berlin.

Simmonds, N. W. 1954. Chromosome behaviour in some tropical plant. Heredity 8 : 139-146.

Singh, B. 1951. Chromosome numbers in some flowering plants. Curr. Sci. 20: 105.

Styles, B. T. and Vosa, C. G. 1971. Chromosome numbers in the Meliaceae. Taxon $20(4): 485-$ 499.

Tixier, P. 1958. Sur le faux Mangoustan: Sandoricum indicum Cav. Journ. Agr. Trop. et. Bot. Appl. 5 (8-9): 596-597.

Zerpa, D. M. De. 1953. Los chromosomas de Melia azedarach. Agron. Trop. (Macaray) 2 (4): 257. 